\title{
Government and Civil Society Partnership in Waste Bank Program in Kediri, Indonesia
}

\author{
Andy Fefta Wijaya ${ }^{a}$, Lely Indah Mindarti ${ }^{\text {a }}$ dan I Made Dwi Permana ${ }^{\text {a }}$ \\ ${ }^{a}$ Universitas Brawijaya, Malang, Jawa Timur, Indonesia
}

INFORMASI ARTIKEL

\section{Article history:}

Dikirim tanggal: 01 February 2016

Revisi pertama tanggal: 10 February 2016

Diterima tanggal: 16 February 2016

Tersedia online tanggal: 16 September 2016

Keywords: Environment, Government, NGO, Waste Bank, Partneship, Reduce, Reuse, Recycle, Civil Society

\begin{abstract}
This research is aimed to address how the patterns of partnership between government and civil society in waste bank program in Perumahan Wilis Indah II Kota Kediri, how its role, the process of what has been conducted in achieving the success of the partnership, and the benefits of each actor and the target group that existence in the partnership. This study used qualitative approach, particularly descriptive analysis. Primary data was collected from interviews, and field observations. Secondary data was collected from documents to complement primary data related to the focus of research such as Act No. 18 Year 2008, Mayor Regulations, Mayor Decisions, Head of SKPD Decisions, RPJMD Kota Kediri, Kediri Waste Characteristic Studies, and Kediri in Figures. This study revealed the partnership amongst government, private, and society use principle of mutual benefit partnersh ip with synergistic partnership. The roles of government, civil society, and NGOs in general they are together make planning and execute the project. In particular, the government has roles as a motivator, endorsement of commitment, setting the rule and law, and also accompany to both physical and non-physical action. For the NGO role is providing assistance in physical and nonphysical action and society as waste bank operator. Based on the process condition theory of which is states that to ensure the success of the partnership there are 12 conditions that should be fulfill, in fact the partnership in waste bank of Sri Wilis Kediri is not all the same as in theory.
\end{abstract}

\section{Introduction}

Public service is responsibility of the Government, the quality of public services organized by government is one indicator in the quality of government such as stated in the 10 principles of adopting good governance, which is efficiency \& effectiveness to guarantee public service delivery by utilizing all available resources optimally and responsibly. Based on this condition, government has set the regulation of Ministry of State for Administrative Reform (MENPAN) number 25 of 2004 to increase the services quality in all sectors. Furthermore, Indonesian government is expected can improve the public services quality after the issuance of Law No. 25 of 2009 regarding Public Services.

Indonesia Governmental System knowing with the mental image of slow, inefficient, and impersonal in delivering public service (Osborne and Gaebler, 1992, p.14). Thus become the core issue regarding the transformation of study in public management and then service quality has become important because of the increasing of national and global competition by use to the satisfaction of public through the government services that given by government should be compatible with the service which is delivered by private sectors.

Waste is the rest of the daily activities of human and/ or natural processes in the solid form, (Law No. 18

* Corresponding author. Tel.: +62-818-0380-5462; e-mail: andyfefta_fia@ub.ac.id 
of 2008). The number or volume of waste will be proportional to the level of consumption of goods or materials that people use every day, so the waste will continue to exist due to human activity with various needs. In fact, population growth and changes in consumption patterns lead to increasing volume, type and characteristics of waste increasingly diverse (Kastaman 2007, h.72). In addition, the amount and the increasing of population growth will also add the problem for the environment, especially on pollution by waste, which everyone estimated generated waste about 2-4 Kg/ day, and other garbage (Bahar, 1986, h.9).

Increasing population, infrastructures development, and try to get better economic growth for some area not only give positive impacts but also in addition have negative impacts. Indonesia, as the fourth most populous country in the world, facing many problems related to environmental sanitation because of trying to reach high economic growth, especially waste management problems. Nowadays the total waste generated by the community is estimated only $60 \%-70 \%$ transported to the landfill by the authorities. Most of uncollected waste that not been collected by the government, usually burned or dumped into rivers and only a small portion is handled by scavengers (Damanhuri, Enri. I Made Wahyu, Ruslan Ramang, Tri Padmi,, 2009). Local governments are trusted party to handle the waste. However, because of the low priority from the government in developing countries, services in waste management are being inefficient and not growing well. Swollen financial, lack of operational funds, low-quality institutions, official indiscipline, lack of trained personnel and political pressures make the situation worse (Joseph, 2006).

Various problems in waste management require a serious handle because of rapid urban growth directly implicated in the development of basic infrastructure and public services. To achieve optimal waste services, now is the time to change the paradigm of municipal waste management. Shifting paradigm of waste management referred to the concept of municipal waste management that can prevent or minimize the generation of pollution and other negative impacts that detrimental to society and the environment. According Witoelar $(2006$, p. 2) it is required a pioneer to change the paradigm of waste management from the end of the pipe approach which dispose of waste directly to Final Disposal Place/ landfill towards the principle of $3 \mathrm{R}$ (Reduce, Reuse and Recycle). Indonesia is yet far behind the other countries in the event of paradigm shift. According Buclet and Olivier (2001: 304) the changes paradigm of waste management in most European countries started since 1970 . Waste management policy focused on waste reduction at source, sorting and recycling. The most important starting point in this paradigm is a change of policy toward the minimization of waste at source, rather than disposal.

Waste sources in Kediri generated from daily activities domestic and non-domestic. Waste originally come from residential areas, markets, shops, offices, tourist attractions, schools, stations, terminals, hotels / restaurants, hospitals, roads and industrial. Kediri Municipality Government have to disposed 146,672 $\mathrm{M}^{3}$ of waste into TPA in 2014. The volume of waste dispose of in landfill over the last 5 years can be seen in the following table.

Table 1 Volume of Waste Dispose of into TPA

\begin{tabular}{lccccc} 
Month & $\begin{array}{c}\mathbf{2 0 1 0} \\
\left(\mathbf{m}^{\mathbf{3}}\right)\end{array}$ & $\begin{array}{c}\mathbf{2 0 1 1} \\
\left(\mathbf{m}^{\mathbf{3}}\right)\end{array}$ & $\begin{array}{c}\mathbf{2 0 1 2} \\
\left(\mathbf{m}^{\mathbf{3}}\right)\end{array}$ & $\begin{array}{c}\mathbf{2 0 1 3} \\
\left(\mathbf{m}^{\mathbf{3}}\right)\end{array}$ & $\begin{array}{c}\mathbf{2 0 1 4} \\
\left(\mathbf{m}^{\mathbf{3}}\right)\end{array}$ \\
\hline January & 12,545 & 13,395 & 13.353 & 12,350 & 12,594 \\
February & 12,480 & 12,658 & 12.434 & 11,179 & 11,396 \\
March & 12,572 & 12,658 & 12.434 & 11,201 & 11,938 \\
April & 15,018 & 12,227 & 11.226 & 13,315 & 12,098 \\
May & 15,177 & 13,151 & 11.652 & 12,720 & 12,964 \\
June & 15,742 & 12,361 & 11.588 & 11,762 & 12,149 \\
July & 15,899 & 12,346 & 11.962 & 12,690 & 12,892 \\
Augusts & 16,036 & 12,646 & 11.404 & 11,404 & 11,885 \\
September & 15,978 & 12,343 & 11.314 & 12,502 & 12,134 \\
October & 14,883 & 12,139 & 12,408 & 12,653 & 12,434 \\
November & 14,883 & 12,139 & 12,028 & 11,712 & 11,991 \\
December & 13,975 & 12,936 & 12,423 & 11,410 & 12,197 \\
\hline \multicolumn{1}{c}{ Total } & $\mathbf{1 7 7 , 0 0 8}$ & $\mathbf{1 6 4 , 5 7 1}$ & $\mathbf{1 4 4 , 2 3 0}$ & $\mathbf{1 4 4 , 8 9 8}$ & $\mathbf{1 4 6 , 6 7 2}$ \\
\hline
\end{tabular}

Source: Department of Sanitation and Landscape Kediri Municipality, 2015

The table above shows that still a lot of the waste that have to disposed of into landfill, and not utilized and not recycled. With the operational system of waste management in Kediri in the form of lug, collection, transfer, and disposed of into TPA, then from day to day number piles of waste in TPA will multiply increase.

To overcome these problems, local governments try to change the paradigm of waste management, which accompanied by an increase in environmental health through waste bank programs. Waste Bank programs are implemented in all sub districts in Kediri. After enacted of Act No.18 of 2008 regarding waste management, local government has the authority to manage their own waste. This is where it takes the role of citizens and the private sector to help governments in planning and organizes the decisions made. Civil society is the space where social groups can exist and move. In general it is a social group includes non-governmental organizations/institutions (NGOs), public institutions in grassroots, media, educational institutions, profession associations, religion organizations, and others as a whole can be a force balancing of government or private sector (Sumarto 2009: 15)

Nowadays, all countries in the world try to encourage the role of three pillars of good governance in the form of partnership amongst government, society as the main producer of waste, and private sector in various fields, including in addressing environmental problems. The Sri Wilis Waste Bank in Kediri, established a partnership amongst Government, Forum Kota Kediri 
Sehat (FKKS) and Society in Kediri. Waste Banks program implementation have a positive impact on the environment around the waste bank, condition in settlements cleaner than before, and there is no smell of waste from the bins located in front of each house, it make people can now do their activities more comfortable and get additional income from waste management.

Related to this study, there are various previous study been conducted and discussing the partnership between government, civil society, and private sector. Some of them that are done by Teguh Kristiyanto (2007) entitled, community participation in sustainable waste management in kebumen. The researcher found that community participation is still low at local level of waste management system. The role of stakeholders in waste management is still only normative. Potential and constraints of public participation can developed into a form of household, communal, and centralized management. Other previous study done by Ridha Fauziah (2014) entitled, Budget Performance of Bank Sampah Malang (BSM): Current Reality and Future Subjects. In this study, the author revealed that even the waste bank program in Malang are not profitable if seen from the economic side, but the social benefit for the citizens and maintain the cleanliness of environmentof the BSM activities exceeds its economic profit. Because of has a lot of social benefit for the citizens, local government maintained the existence of BSM by giving subsidies every years.

Judging from the results of previous studies that the partnership does not always make the program or objectives are achieved. To see the success that obtained by Sri Wilis Waste Bank, which is located in Perumahan Wilis Indah II Gang 13 No. 1, with the synergy between government and civil society make the authors wanted to examine the partnership that already conducted.

This research are going to address how the patterns of partnership between government and civil society in waste bank program in Perumahan Wilis Indah II Kota Kediri, how its role, the process of what has been conducted in achieving the success of the partnership, and the benefits of each actor and the target group that existence in the partnership.

To answer these problems, this study used qualitative approach, particularly descriptive analysis. Primary data was collected from interviews, and field observations. Secondary data was collected from documents to complement primary data related to the focus of research such as Act No. 18 Year 2008, Mayor Regulations, Mayor Decisions, Head of SKPD Decisions, RPJMD Kota Kediri, Kediri Waste Characteristic Studies, and Kediri in Figures. Data validity tested through triangulation sources of data to obtain the validity of the data in this study. Data analysis conducted by condensation the data that is choosing or sorting things that are important, data presentation, and conclusion.

\section{Theory}

The first part of the Act of partnership, 1890, defines partnership as follows, a relationship that arising among people to running a business with the objective to get benefit (in Ibrahim 2006:26). Partnership theory developed by Cheeseman contains, partnerships or known by the term alliance is voluntarily of two or more people to work together in business activities and become partners to get benefit. The form of partnership raises their rights and obligations between them. Rights and obligations of the parties expressed in the agreement partnerships or determined by law (in Ibrahim 2006:26).

Partnership refers to Mohr and Spekman is a strategic relationship that is intentionally designed or built between companies to achieve the intended purpose, mutual benefit and highly mutual dependence (in Jane 2011: 193). Meanwhile, according to Farazmand, Partnership is a voluntarily activities to achieve the common goal or target of the organization. In the sound governance context, partnership requires participation from all stakeholders, meaning all components of governance, including government, private, and citizens who have stakes in the governance process, (in Mardiyanta 2011:15).

According Sumarto (2009: 116) a partnership is relationship between government, society, and private in order to achieve a goal that based on the principles of trust, equality, and independence. According to Anderson, quoted by Ibrahim (2006: 26) describes the general characteristics of a partnership made by all the parties that involve, in terms of the partnership are:

a) Arises because of the desire to hold a consensual relationship, where the desire arises not because governed by law but come from each private party;

b) Always involves elements such as capital, labor, or a combination of both; and

c) Generally consists of companies (firms) and its partners.

Kouwenhoven argued to guarantee the success of the partnership, the necessary the following conditions are also known as process conditions, namely (Kooiman 1993: 125):

a) Mutual trust;

b) Sufficient project organization;

c) Surveillance of all parties rights and interests;

d) Clear and note division of authorities and responsibilities;

e) Clear Step of the project;

f) Regulation of how to settle the conflict lay down beforehand;

g) Legality and law; 
h) Obvious and registration division of risks, costs, and returns;

i) Sufficient control and support facilities;

j) Market oriente and business thinking and acting;

k) Internal control and coordination; and

1) Clear strategy and objectives or goal.

According to the Indonesian Dictionary (1994) definition of the pattern of is a model of the system, how the (governmental) or form (structure) that fixed. The partnership scheme according Sulistiyani (2004: 130131) inspired by the lives phenomenon biological organism, which tried to lift into understanding and then divided into the following:

a) Pseudo partnership

Pseudo partnership is an alliance between two or more parties but they did not actually cooperate with each other in a balanced manner. Even at a party is not necessarily correctly understand the meaning of an alliance is done, and for the purpose what it was all conducted and agreed. There is a unique partnership of this pattern, that the two sides or more equally feel it is important to cooperate, but the parties do not necessarily understand the substance to partnered championed and what its benefits.

b) Mutualistic Partnerships

Mutualistic Partnership is an alliance of two or more parties that each other realize the importance of the partnership aspect, for mutual benefit and get more benefits, so it will be able to achieve more optimal benefit if they work together as a partner. From the understanding of the importance of partnership, the two agencies/ organizations or more who have equal or different status to cooperate. Benefits crisscrossed between the parties to cooperate can be obtained, making it easier for each to realize the vision and mission and also mutually supporting each other.

c) Conjugation Partnership

Conjugation Partnership is a partnership that is analogous Conjugation of life paramecium. Two paramecium do conjugation to gain energy and can execute the division, and then separated from others. From the analogy of the organizations if we look from beginning startup, agencies, groups or individuals who have a weakness in the conduct of business or organization can achieve a partnership with these models. Two or more parties can do conjugation in order to increase the capabilities of each.

While other partnerships developed based on the principles of organizational, in general life are (Sulistiyani 2004: 131-132):

\section{d) Subordinate union partnership}

The partnership that basis of the merger of two or more parties that become subordinate to others. This kinds of partnership between two or more parties who have status, ability or force balance each other. The relationship whice created not in a straight line equal to one another, but in the upper and lower relationship, strong and weak. Therefore, this condition has resulted in no sharing and the role or function of the balance.

e) Linear union partnership

Partnership whic is through the merger of the parties in a linear or straight line. Thus parties joined forces to carry out cooperation is the organization of the parties that have similar relative. The similarity can be a goal, or mission, the amount/ volume of business or organization, status or legality.

f) Linear collaborative partnership

The context of this partnership does not distinguish between the amount or volume, status/ legality, or the strength of the parties in partnership. Which became the main pressure is the vision-mission complementary to each other. In this partnership established a linear fashion, which is located on a straight line, not subordinate to each other.

Meanwhile, according to the OECD cited by Mahmudi (2007: 53-67) that the operation-maintenance, turnkey types operation, design-build, leasing, temporary privatizes, wrap around addition, rent-buildoperation, build-transfer-operation, build-ownoperation-transfer, build-own-operation

Government in Indonesian means briefing and administrative authority over activities people in a country, state, or city. Government is a system that governs all activities of the community in an area / region/ country, which covered all aspects of life based on certain norms. According to Leach \& Percy-Smith, politicians and government that set up, do something, give service, while the rest of us is a passive recipient that what Government implies (in Sumarto 2009: 2). Local governments, according Sarundanjang (1999: 228-237) in the future at least have the following characteristics:

a) The local government, which is, patterned entrepreneurship. Is a Government that utilizes three resource components that they have: Government, Private sector, and Civil Society.

b) Local governments that have public accountability. Accountability is namely as an obligation of local government with all elements of the bureaucracy in providing accountability to the public regarding various government activities, including its performance in the public service.

c) The local government that characterized by good governance

Theoretically, good governance implies that power management is based on rules of law, transparent policy-making, and accountability to the public.

d) Transparency in local government

Transparency does not mean nudity, but openness in the true sense, which provides rights and an 
opportunity for the public to know all the various local government activities relating to the life of society.

According to the Indonesian Dictionary, civil society is a society that upholds the values, norms, and laws are underpinned by the mastery of the faith, science, and technology that civilized (in Hasim 2010: 55). In his book entitled inovasi, partisipasi, dan good governance, Sumarto (2009: 15), describes civil society as a space where social groups can exist and move. In general what is meant by social groups include nongovernmental organizations/ NGOs, public institutions at the grassroots, religious organizations, media, educational institutions, professional associations, and others organization outside government that the can be a strength, and balancing power of government and the private sector.

By Permen No. 13 of 2012, Waste Bank is a place for sorting and collection of waste that can be recycled or reused and that have economic value. Waste bank has the objective to educate and civilize waste reduction at the community level as well take the economic benefits of their implementation.

\section{Result and Discussion}

\subsection{Partnership Form Between Government and Civil Society at the Waste Bank Program in Waste Bank of Sri Wilis Kediri}

In carrying out the shift of waste management paradigm in Kediri, Kediri municipal government reform it from the non-physical and physical activities. Physically, such as construction of TPS and Composting House, renovation of TPS, vehicle purchases such as: dump truck, motor carts, as well as the purchase of waste carts that separates organic and an organic waste. In addition to the physical form, a paradigm shift accompanied by an increase in environmental health through waste bank programs. In running a paradigm shift, especially in the waste bank program, Kediri government chose a partnership between governments, civil society and NGO (Forum Kota Kediri Sehat). Partnerships among the three parties are good and it had a positive impact in changing the behavior of community in term of how they handle and perception regarding waste.

The partnership between government, civil society, and private identically to the pattern of mutualistic partnerships form. This is because the partnership that exists to support each other to realize the goals that already set. In addition, the partnership is motivated seeing the reality of waste management in Kediri Municipality which is tends to have a negative impression, especially in the field of environment, such as mounting even waste strewn, muddy, etc. For that, they have the awareness to change the situation for the better neighborhoods. In realizing the objectives they realize, will be easier to achieve if done together. The Mayors endorse partnership in the establishment of waste bank between government and society.

\subsection{The Role of Government, Society and NGOs in Waste Bank Program in Waste Bank of Sri Wilis Kediri}

In a partnership, actors have their respective roles. Broadly speaking, three actors have the same role in this partnership is to run this partnership, from planning to implementation. In more specific, the government has roles as a motivator, endorsement of commitment, setting the rule and law, and also accompany to both physical and non-physical action. For the NGO role is providing assistance in physical and non-physical action, in the form of capacity building by training, comparative studies, etc. for the community have a special role is to operate the waste bank once a week.

\subsection{Process that Done to Achieve Partnership Success in Waste Bank Program in Waste Bank of Sri Wilis Kediri}

Based on the process condition theory which is states that there are 12 conditions that can ensure the success of the partnership, in fact the partnership in waste bank of Sri Wilis Kediri is not all the same as theory. On partnerships in the waste bank of Sri Willis in Kediri, not previously defined strategy but each actor has a different strategy to obtain the goal of this program. As from the society as a waste bank's operations have a strategy to encourage people to save in a pick up the ball, that will provide trash pickup services to an area close to the location of the waste bank. In addition, the provisions regarding the risks and benefits are not carried out in this partnership.

Orientation of thought and action is also unfounded business and market, because in basically the partnership that established is a partnership in social environment, not a economically benefit partnership in the business field. Although there is a difference between process condition theory and what already done at the waste bank sri wilis, the partnership that exists in the waste bank program in Kediri going well and bring a positive impact. The difference in these conditions do not affect significantly in this partnership.

\subsection{Each Actor and the Target Group Benefits of the existence of the Partnership Program in Waste Bank of Sri Wilis in Kediri}

From this partnership, the three actors have their own benefit either directly or indirectly. At the government side, the benefit that received are change in people's behavior become cleaner and the environmental conditions were also clean. For the society, acquire knowledge, additional income, and also experience from the waste bank. For NGO, the benefit received is not directly but from the involvement of the NGO's 
participating in this partnership makes Kediri better and some employees start saving in waste bank program.

Besides the actors involved, target groups there was also benefiting from this partnership. There are many benefit obtained by the community from this waste bank program such as, the public more aware of the importance of the economic value of waste, earn extra money, and also getting cleaner housing conditions so as to increase the sale value of the property.

Those positive externalities are in line with the purpose of Bank Sampah Sri Wilis. The purposes of the Bank Sampah Sri Wilis are as follows:

a) Shift citizens' perception toward waste. The waste which considered as the rest of a process and not have a value, if managed or separated properly, will have economic benefit;

b) Increasing citizens' participation to reduce, reuse, and recycle the waste in managing their own waste in order to implement government regulations and obligations; and

c) Collect and manage the waste directly from the source, so that the waste that has to transport to the final disposal site can be reduced.

Establish Kediri Municipality as a clean, healthy, and environmentally friendly city.

\section{Conclusion}

Based on the results of data analysis and presentation of research results, it can be concluded as follows:

The partnership between government, private, and society, in the waste bank program in Kediri use mutualistic partnerships form. The roles of government, society, and NGOs in general they are together make planning and execute the project. In particular, the government has roles as a motivator, endorsement of commitment, setting the rule and law, and also accompany to both physical and non-physical action. For the NGO role is providing assistance in physical and non-physical action and society as waste bank operator.

The process has been done to achieve successful partnerships in waste bank program are:

a) Mutual trust: in running this partnership the three actors trust each other and to date there has been no significant problems among the actors;

b) Clear strategy and objectives or goal;

c) Obvious and registration division of risks, costs, and returns;

d) Clear and note division of authorities and responsibilities;

e) Clear Step of the project such as : planning, coordination across sectors, which is proposal on formation of Waste Bank submitted to the government. After that, strengthened by the creation
SK of Kediri Mayor about Waste Bank and then forming Waste Bank Group business;

f) Prepare conflict regulation.

g) Make regulation and legal entity.

h) Surveillance of all parties rights and interests.

i) Sufficient control and support facilities for running waste bank

j) Make an intense internal coordination from the actors, done by FGD (Focus Group Discussion).

k) Adequate project organization that business group. They run the waste bank program properly and responsibly

\section{References}

Ahmed, S. A., \& Ali, M. (2004). Partnerships for solid waste management in developing countries: linking theories to realities 1. Habitat International, 467-469.

Anschütz, J. (1996). Community-based solid waste management and water supply projects: problems and solutions Compared. Urban Waste Expertise Programme (UWEP), Community Participation in Waste Management. UWEP Working Document.

Bahar, Y. H. (1986). Teknologi Penanganan Sampah dan Pemanfaatan. Jakarta: Wacana Utama Pramesti dan Pemda DKI.

Berry, F., Chackerian, R., \& Wechsler., a. B. (1995). Reinventing Government: Lessons from a State Capitol." In Public Management Reform and Innovation: Tuscaloosa: University of Alabama Press.

Broadbent, J., \& Guthrie, J. (1992). Change in The Public Sector A Review of Recent Alternative Accounting Research, Accountng, Auditing \& Accountability. Auditing \& Accountability Journal Vol 5 no.2.

Buclet, N., \& Godard, O. (2001). The Evolution of Municipal Waste Management in Europe. Journal of Environmental Policy and Planning .

Damanhuri, Enri. I Made Wahyu, Ruslan Ramang, Tri Padmi,. (2009). Evaluation of Municipal Solid Waste Flow in the Bandung Metropolitan Area Indonesia. The 3rd expert Meeting in Solid Waste Management in Asia and Pacific Islands. -: - .

Denhardt, J. V., \& Denhardt, R. B. (2007). New Public Service, Serving not Steering. New York: M.E. Sharpe, Inc.

Dilulio, J. J., Garvey, G., \& Kett, a. D. (1993). Improving Government Performance: An Owner's Manual. Washington, DC: Brookings Institution.

Fauziah, R. (2014). Budget Performance of Bank Sampah Malang (BSM): Current Reality and Future Subjects. 
Fernandez, A. (1997). Recycling in Asia: Partnerships for Responsive Solid Waste Management Introduction. Nagoya, Japan: United Nations Centre for Regional Development.

Frederickson, H., Smith, K., Larimer, C., \& Licari, M. (2002). The Public Administration Theory Primer-2 nd ed. Philadelphia: Westview Press.

Garson, G., \& Overman, E. (1983). Public Management Research in The United State. New York.

Hadi, S. (2004, December 7). Rubbish syndrome. Kompas .

Hasim. (2010). Civic 2 Education. Jakarta: Yudhistira.

Henry, N. (1989). PublicAdministration and Public Affairs,fouth edition,. New Jersey: Prentice Hall,Englewood Cliffs.

Hickman (Jr.), H. (1999). Principles of Integrated Solid Waste Management. USA: American Academy of Environmental Engineers.

Hood, C. (1991). A Public Management for All Seasons' Public Administration Vol. 69.

Hughes, O. E. (2003). Public Management and Administration : An Introduction. 3rd ed. New York: Palgrave Macmillan.

Hughes, O., \& O'neill, D. (1998). Public Management and Administration; An Introduction. . New York: St. Martin Press.

Ibrahim, J. (2006). Hukum Organisasi Perusahaan. Bandung: PT. Refika Aditama.

Ife, J., \& Tesoriero, F. (2006). Community Based Alternatives in an Age of Globalization. Australia: Pearson Education.

IGES. (2006). Policy Dialogue Working Paper Series \# 2. . Asia Pacific Forum for Environment and Development (APFED) Expert Meeting on the $3 R$ s in Asia (pp. 1-26). Tokyo: Institute for Global Environmental Strategies.

Jane, O. (2011). Analisis Potensi Partnership sebagai Moda untuk meningkatkan Kapabilitas Inovasi dan Teknologi. Vol.7, no.2.

Joseph, K. (2006). Stakeholder Participation for Sustainable Waste Management. Habitat International.

Kastaman, R. d. (2007). Sistem Pengelolaan Sampah Terpadu; SILARSATU. Bandung: Humaniora.

Kodoatie, R. J. (2005). In Pengantar Manajemen Infrastruktur (p. 27). Yogyakarta: Pustaka Pelajar.

Kooiman, J. (1993). Modern Governance. London: SAGE Publications.

Kristiyanto, t. (2007). Community Participation in Sustainable Waste Management in Kebumen.

Lan, Z., \& Rosenbloom, D. (1992). Public Administration in Transition? (Editorial), Public Administration.

Mahmudi. (2007). Kemitraan Pemerintah Daerah dan Efektivitas Pelayanan Publik.Vol.9 No.1.
Mahmudi. (2005). Manajemen Kinerja Sektor Publik. Yogyakarta: VPP AMP YKPN.

Mardiyanta, A. (2011). Kebijakan Publik Delibratif. Vol. 24, No.3.

Osborne, D. G. (1997). Reinventing Government, Alih Bahasa Abdul Rasyid, 1997, Mewirausahakan Birokrasi: Mentransformasikan Semangat Wirausaha Kedalam Sektor Publik. Jakarta: Pustaka Binamas Pressindo.

Pamudji. (1985). Kerjasama Antar Daerah. Jakarta: Balai Pustaka.

Pollit, C., \& Bouckaert, G. (1999). Public Management Revorm:A Comparative Analysis. London: Oxford University Press.

Prawirokusuma, S. (2001). Ekonomi Rakyat (Konsep, Kebijakan dan Strategi). Yogyakarta: BPFE.

Purwadarminto, W. (1997). Kamus Umum Bahasa Indonesia. Pusat Pengembangan dan Pembinaan Bahasa, Departemen Pendidikan dan Kebudayaan. Jakarta: Balai Pustaka.

Riggs, F. W. (1996). The Ecology of Public Administration. london, new york: Asian Publishing House.

Rosenbloom, D. H., \& Kravchuck, R. S. (2005). Public Administration, Understanding Management, Politics and Law in The Public Sector. New York: McGraw-Hill.

Sarundajang. (1999). Arus Balik Kekuasaan Pusat ke Daerah. Jakarta: Pustaka Sinar Harapan.

Sudradjat. (2007). Mengelola Sampah Kota. Jakarta: Penebar Swadaya.

Sulistiyani, A. T. (2004). Kemitraan dan Model-Model Pemberdayaan. Yogyakarta: Gava Media.

Sumarto, H. S. (2009). Inovasi, Partisipasi,dan Good Governance. Jakarta: Yayasan Obor Indonesia.

Syafrudin. (2006). Buku Ajar Pengelolaan Limbah Padat (Sampah) Perkotaan. semarang: Program Modular Magister Teknik Manajemen Prasarana Perkotaan Universitas Diponegoro.

Tchobanoglous, G., Theisen, H., \& and Vigil, S. (1993). Integrated Solid Waste Management: Engineering principles and management issues. Singapore: McGraw Hill, Inc.

TEI, \& Sasaki. (2006). Better Practice of Waste Management in Thailand. . Proceedings of the APFED Expert Meeting on the 3Rs in Asia (pp. 117). Bangkok: Thailand Environment Institute.

TERI. (2006). Types of solid waste. New Delhi: The Energy Research Institute.

UNEP. (2005). Strategic Elements in Implementing the 3R Platform: UNEP's contribution. the UNEP $3 R$ Ministerial Meeting of April 2005. Japan: United Nations Environment Programme.

UNOPS. (2007). National Solid Waste Management Policy and Support to Private Sector 
Participation in Waste Management Services. National Solid Waste Management Policy issue. Maldives: United Nations Office for Project Services. .

WALSH, K. (1995). Public Services and Market Mechanisms.Competition, Contracting and the New Public Management . Basingstoke and London.

Witoelar. (2006). Retrieved from Mari Tinggalkan Cara Lama: http://202.146.5.33.UNILEVERPEDULI

Yarianto, e. (2005). Perlu Paradigma Baru Pengelolaan Sampah. Retrieved from http://www.sinarharapan.co.id. 